\title{
3 Commemorating genocide in Rwanda
}

\author{
Erin Jessee
}

\section{Introduction}

Today, we pause to reflect on the tragedy we experienced and what we lost, both individually and as a nation. We will continue to educate new generations of Rwandans about what happened to our country, and what we learned from it.

We are putting those lessons into practice for the benefit of those who come after us. The lessons of our history have united us. They teach us the value of good leadership that cares for the well-being of all citizens.

Rwanda's President, Paul Kagame, delivered these words to the Rwandan public and the international community on 7 April 2020 to launch Kwibuka 26 , the 26th annual commemoration of what is referred to in official parlance as the "1994 genocide against the Tutsi". The genocide occurred at the height of international efforts to negotiate an end to a three-year civil war that had been triggered when the predominantly Tutsi Rwandan Patriotic Front (RPF) - a party composed primarily of descendants of Tutsi refugees who had fled earlier periods of political violence in Rwanda - invaded northern Rwanda on 1 October 1990. The conflict, and broader climate of economic, social and political upheaval, radicalized a cohort of Hutu Power extremists close to Hutu President Juvénal Habyarimana (in power from 1973-94), who began disseminating anti-RPF and anti-Tutsi propaganda aimed at demonizing the RPF and its perceived supporters, Rwanda's Tutsi minority population. Following Habyarimana's unexpected assassination on 6 April 1994 by unknown parties, the Hutu Power extremist-dominated interim government used the resulting chaos as an opportunity to attempt to eliminate political moderates and the nation's minority Tutsi. The genocide lasted approximately three months, culminating with the RPF's military victory on 18 July (Des Forges 1999; Guichaoua 2015; Kimonyo 2016). By this time, the Hutu Power extremists and their supporters had massacred between 500,000 (Des Forges 1999, pp. 15-16; Meierhenrich 2020, p. 81; Straus 2019) and one million (National Commission for the Fight Against Genocide 2013) Rwandans and sexually assaulted an estimated 250,000 women, among other atrocities (Degni-Ségui 1996; Nowrojee 1996). Most of the Hutu Power extremists'

DOI: 10.4324/9781003167280-4 


\section{Erin Jessee}

victims were of Tutsi heritage, but they also targeted "internal enemies": the Tutsi's perceived supporters among the Hutu majority and indigenous Twa minority (Eltringham and Van Hoyweghen 2000, p. 226; see also Laws et al. 2019; Lewis and Knight 1995, pp. 26-7).

The 1994 genocide represents one of the few examples of mass atrocity since the Holocaust that has met the legal criteria established by the United Nations Convention on the Prevention and Punishment of the Crime of Genocide (1948). Internationally, legal accountability was partially pursued via the nowdefunct International Criminal Tribunal for Rwanda (ICTR). However, the RPF's transitional government has also pursued an ambitious transitional justice programme comprised of national trials and an adapted dispute resolution mechanism known as gacaca ("justice on the grass") (Doughty 2016; Gahima 2013; Ingelaere 2016). Additionally, the government has increasingly invested in a comprehensive national commemoration programme that includes eight major genocide memorials and provides support for nearly 250 district-level genocide memorials that are maintained by local communities (National Commission for the Fight Against Genocide 2020). These memorials - the focus of this chapter - are integral to official genocide commemoration in Rwanda. They have been designed to adhere to key international transitional justice principles: providing survivors with a safe place to remember their missing and murdered loved ones; educating the public about Rwandan history leading up to the genocide, including the dangers of "bad governance" and ethnic divisionism; and providing irrefutable evidence - most notably through the displaying of visibly traumatized anonymous human remains and personal effects - that the violence that overwhelmed Rwanda in 1994 constitutes genocide (Jessee 2017, p. 46). The memorials thus serve as focal points for official genocide commemoration and education.

Kagame's speech for Kwibuka 26 cited in the opening passage similarly aligns with many key principles of international transitional justice, most notably by appealing to Rwandans' sense of shared national heritage and encouraging them to learn from those aspects of Rwandan history that made the genocide possible to prevent future genocidal violence. However, Kagame's words obscure the ongoing controversy that surrounds nationalized genocide commemoration in Rwanda, as commemorative sites and ceremonies have evolved to recognize an increasingly limited and politicized version of events, which perpetuates a "nationalism-within-a-nationalism" (Baldwin 2019, p. 2). Scholars have studied nationalized commemoration in Rwanda from various disciplinary perspectives (see, for example, Burnet 2009; Friedrich and Johnston 2013; Guyer 2009; Ibreck 2013; King 2010; Major 2015; Meierhenrich 2011; Mwambari 2019; Vidal 2004; and Viebach 2019). Anthropologist Claudine Vidal (2004) was one of the earliest scholars to study Rwanda's memorials, and argued that they were becoming a source of symbolic violence that silences survivors' lived experiences and dictates how they interact with their murdered loved ones. Soon afterwards, transitional justice scholar Susanne Buckley-Zistel (2006, p. 131) found that the 
memorials and related commemorative practices were prompting Rwandans to practise "chosen amnesia" - a survival mechanism that enables peaceful coexistence while failing to challenge "the social cleavages that rendered the genocide possible in the first place, and so obstructing their transformation in the future". Anthropologist Jennie Burnet (2012, p. 128) subsequently argued that the official narrative upheld by Rwanda's national commemorative sites and events promoted "a clear yet sometimes arbitrary demarcation between Hutu and Tutsi" that recognizes only Tutsi victims, while condemning the Hutu majority as perpetrators.

This critical research speaks to two key themes in the literature on official genocide commemoration in Rwanda: the state-imposed official narrative of the genocide and the silences that it inevitably imposes on those Rwandans whose experiences do not neatly align with this narrative; and the ensuing question of whether the Rwandan government's increasingly politicized approach to commemoration can truly facilitate genuine social repair and long-term political stability in the region. However, a politicized approach to commemoration is by no means unique to Rwanda (see, for example, Drozdzewski et al. 2016; Rose 2016; Sodaro 2018; Winter 2007; see also Chapter 2 in this volume), nor are these themes without their own critics. As noted by peace-building scholar David Mwambari (2019, p. 2), studies of individual Rwandans' efforts to commemorate their experiences of the genocide, using music and the arts, have been largely eclipsed by studies of genocide memory "at the centre of national politics, foreign policy-making and socio-economic programs in what has a become an authoritarian political climate" (see also Longman and Rutagengwa 2006; Viebach 2019). Those few studies that focus on, or include, analysis of Rwandan genocide commemoration "from below" reveal the "limits of a government's ability to shape the collective memory of a population", highlighting the need for more complex, multilayered analysis that goes beyond ethnic identities to consider political, regional, gender and other salient markers of identity in Rwanda (Longman and Rutagengwa 2006, p. 243). Indeed, individual survivors and their narratives have been, and remain, significant actors who inform Rwanda's official narrative of the genocide - even in instances where they recognize the official narrative's inability to adequately represent the diverse experiences of the genocide and the significant challenges it poses for promoting genuine national unity and reconciliation in Rwanda (Jessee 2017, pp. 81-116). As political scientist Rachel Ibreck (2012, p. 99) reminds us, "we must expect fractured memory in Rwanda", given people's polarizing experiences of genocide and related mass atrocities in the 1990s.

\section{The first national genocide commemorations}

The effects of people's polarizing experiences, and the fractured memory that has resulted, became evident with Rwanda's first efforts to commemorate the genocide. Immediately after its military victory, the RPF established a 
government of national unity led by Hutu President Pasteur Bizimungu and Tutsi Vice President Paul Kagame. Central to their government's platform was the promotion of a shared national identity, which they argued should obliterate the ethnic identities that had increasingly divided Rwandans in the 20th century (Blackie and Hitchcott 2018, p. 24; Benda 2019, p. 191). Burnet (2012, p. 96) notes that the first national genocide commemoration in April 1995 at Kigali's National Amahoro Stadium "promoted the ideology of national unity through representation of both Tutsi and Hutu victims of the genocide". The ceremony included the burial of 6,000 anonymous victims of the genocide, as well as recognition of national heroes such as former Prime Minister Agathe Uwilingiyimana - the moderate Hutu politician who had been slated to succeed Habyarimana (Burnet 2019; Guichaoua 2015, pp. 214-20) - who was murdered by Hutu Power extremists on 7 April 1994 to eliminate resistance to the genocidal interim government they were forming. This first commemoration aligned with the broader tendency in official state discourse and Rwandan popular culture to reference itsembabwoko n'itsembatsemba ("genocide and massacres"): phrasing that not only acknowledged Tutsi victims of genocide, but also Hutu and Twa who were murdered during the genocide for resisting Hutu Power ideology or by the RPF as it wrested control of Rwanda, among other forms of political violence (Burnet 2012, p. 20).

Meanwhile, across Rwanda the government partnered with formal and informal genocide survivors' associations that emerged shortly after the genocide ended - the most prominent of which is the umbrella organization Ibuka founded in December 1995 - to create genocide burial grounds and memorials in their communities. This set an important precedent for the creation of small-scale genocide memorials throughout Rwanda, as well as the larger national memorials that since 2007 have been administered by the National Commission for the Fight Against Genocide (CNLG). Ibreck (2010, p. 336) argues that while survivors gained an important political platform through these institutions and associated activities, they saw this early memory work "as a response to loss and ... first and foremost an expression of grief and a practice of mourning", a kind of "memory-justice" (see also Viebach 2020, p. 240). Survivors' organizations worked with the government to locate mass graves and related sites where the Hutu Power extremists disposed of their deceased victims' bodies, and exhume, clean and rebury with respect the human remains they found - an important form of "care-taking" for survivors' loved ones (Viebach 2019, p. 278; see also Major 2015, p. 165). Fabrice, a child survivor of the massacre at Kibuye Roman Catholic Church in western Rwanda, remembered the process in his community as follows:

What we did is just to collect all the human remains, clean them and bring them to the memorials. While collecting the bones, we didn't identify who those people were. Everybody treated the bones as though 
they belonged to his or her family. It was participatory work, where even those who didn't know where their people were buried contributed.

(Jessee 2012, p. 10) ${ }^{1}$

Vidal (2001, p. 4, author's translation) argues that while such practices represented a "radical symbolic rupture" from earlier Rwandan traditions associated with respectful treatment of the dead, many survivors embraced this change because they believed it served "an existential purpose: the will to restore the deceased's human dignity, a dignity that the instigators and perpetrators of the genocide had denied both with their propaganda and by the cruelty of the suffering they had inflicted upon their victims". Which is not to say, of course, that these exhumations were easy for the people who participated in them. During fieldwork I conducted between 2007 and 2012, most of the Rwandan survivors whom I interviewed recalled these exhumations, and the memorial sites at which the exhumed human remains were eventually reburied, as sources of significant spiritual and emotional distress (Jessee 2012, 2017, pp. 107-9). I found that this distress often persisted despite the underlying intent of the exhumations to prevent the "ills, troubles and misfortunes" that Rwandans feared would come from "deaths for which funeral rites and formal mourning practices are not possible" (Bagilishya 2000, p. 347).

Indeed, the early commemorative initiatives around which these reburials occurred often proved controversial and painful for Rwandans and contributed to heightened tensions in many communities. A key source of tension, in addition to the challenges of exhuming and anonymizing Rwanda's countless mass graves, related to the tendency for these events to be inclusive of the victims of the genocide and related mass atrocities in 1994. In Butare in December 1994, for example, Vidal recalls that the Catholic diocese asked its community to help create a list that included the names of Tutsi and Hutu victims of the genocide and war. In doing so, it acknowledged that many Rwandans would find this process challenging because it required a "renouncement of the natural inclination to seek revenge", but stressed that it was essential to overcome the "evil" that had overwhelmed Rwanda (Vidal 2004 , p. 2). This was followed by survivor-led efforts to disinter the anonymous dead from local mass graves and to rebury them with respect.

Unsurprisingly, the diocese's efforts to encourage recognition of the genocide and related mass atrocities encountered challenges, including a persistent silence within some communities when people were asked to divulge the locations of mass graves. In October 1995, the diocese claimed that "the refusal to divulge [the location of] these [mass graves] is due to the fear of reprisals by genocide survivors or the authorities" (Vidal 2004, p. 4). When they found mass graves and people were able to rebury the remains that they exhumed, in the subsequent ceremonies "verbal abuse prevailed over mourning", as officials condemned the Hutu as a community for perpetrating genocide and survivors publicly accused the people whom they held 
responsible for torturing and/or murdering their loved ones (p. 2). Additionally, the inclusion of public discussion of Hutu victims, especially those who were allegedly murdered by the RPF's military arm - the Rwandan Patriotic Army (RPA) - soon triggered official disapproval. These crimes "were so violently denied by the RPF that their evocation became the subject of a taboo that was dangerous to transgress" (p. 4).

Thus, the Rwandan government was compelled to take control of exhumations and resulting commemorative sites and activities, circumnavigating the questionable authority of the Catholic Church in such matters (Kubai 2007; Longman 2010; Van Hoyweghen 1996). The government's initial involvement, however, fuelled controversy as it began to use prisoners including accused génocidaires - to exhume and transport human remains to the sites of future memorials, even in instances where survivors had already identified their murdered loved ones and held appropriate funerals. Vidal (2004, p. 5) argued that the government's methods created "a climate of revenge more than a demand for justice", which was then reinforced during the 1996 national commemoration. While the previous year's ceremony had focused on Rwandan victims of all ethnicities, during the 1996 national commemoration a Tutsi survivor gave his testimony, after which he began pointing to people in the crowd who he claimed had killed (p. 7). Burnet (2012, p. 101) argues that this ceremony set an important precedent for distinguishing Tutsi genocide victims and survivors from the RPF "rescuers" and Hutu perpetrators - a pattern that persists to the present day, even as other aspects of national commemorations have evolved.

\section{Towards commemoration of the "1994 genocide against the Tutsi"}

To this end, when I first started conducting fieldwork in Rwanda in 2007, the nation was on the verge of a dramatic shift in official discourse related to the genocide, as the government was introducing the exclusive terminology Jenoside yakorewe Abatutsi ("the genocide against the Tutsi"). Martin Ngoga (2020) - the former Prosecutor General for Rwanda and a former Special Representative to the ICTR - argues that use of this terminology is supported by ICTR jurisprudence, while failing to use it "is dangerous as it feeds into an already resurgent denialist movement in the region and internationally". Similarly, Rwandan officials and survivors' organizations often cite a moral argument that equates the recognition of non-Tutsi victims of the genocide, or the discussion of the other forms of political violence that occurred around the 1994 genocide, with a kind of genocide denial (see, for example, Rugira 2020).

This resulting shift in discourse was documented by Ibreck (2012, p. 103), who concluded that it "alters the context in which the commemorations take place and means that Tutsi victimhood is now securely established in public discourse". This was followed in 2009 by the CNLG's decision to name the annual official commemoration ceremony Kwibuka ("to remember"), 
accompanied by appropriate branding for the event. The associated activities, and form and phrasing of the resulting signage and related souvenirs is strictly controlled by the CNLG, which removes any materials that do not conform. The effect is that "visual and aural reminders of ethnicity and violence appear overnight on 7 April and disappear just as quickly overnight on 3 July" (Baldwin 2019, p. 11).

The years immediately surrounding these amendments to the national genocide commemoration in Rwanda were tense. As the Rwandan government began use the media to sensitize Rwandans and the international community as to why the official label was more appropriate, Rwandans from a range of backgrounds relative to the conflict expressed concerns. They feared that this label obscured recognition of the Hutu and Twa political moderates who were murdered from 6 April onwards, as well as the Hutu and Twa civilians who were murdered for trying to resist the genocidal violence. It was felt that such details ought to be highlighted rather than obscured if the goal was to promote genuine national unity and reconciliation (Jessee 2017, pp. 512). This concern arose amid the broader tensions people noted as the state exercised increased authority over national commemorative sites and activities across Rwanda. For example, Consolée - an employee at one of the national memorials - was initially dismissive of questions about the level of public support for the memorials, arguing:

We [survivors] prefer our people to stay at memorials as physical evidence of the genocide, and also we want people from abroad like you to tell others what happened. We want our history to be remembered by the younger generations of Rwandans and also by the entire world.

However, Consolée later acknowledged that displaying human remains or burying genocide victims in mass graves was culturally inappropriate and a source of tension within her community, because these practices had been given priority over even tentatively identifying the victims. She claimed to know many people who believed that they were haunted by the disrespected spirits of family members who had gone missing during the genocide, or were distressed by the possibility that their loved ones might still be alive somewhere:

The harms come when a survivor thinks that maybe his or her people have been eaten by wild dogs or have been buried in a disrespectful way, or maybe they are still alive and are living somewhere else since you are not really sure where they are buried ... It happens to some people: you may hear someone speaking to his or her relative who died. Most of the cases are traumatized people. And also there are some people who dream while they are awake. When you talk to them, they say they were talking to their dead relatives. 
Consolée concluded that if the government dedicated resources to locating, identifying and allowing survivors to repatriate the anonymous victims of the genocide according to their preferences - whether in single burials on ancestral land according to tradition or in the memorials - it would go a long way towards repairing some of the psychological and spiritual damage endured by genocide survivors.

Other memorial staff whom I interviewed were similarly divided on the subject of the memorials' prominent displays of human remains, though all of them acknowledged its negative potential for those survivors who associated "traditional" burials by their family's standards with closure and demonstrating respect for deceased loved ones. For example, Solange - a young survivor who interpreted her work at a genocide memorial as essential for preventing future bloodshed - was conflicted about the site's graphic displays of human remains. She maintained that it was important to show visitors physical evidence of the genocide, noting that "I want people to understand that genocide really happened, because some people doubt it ever took place or deny it. My aim is to make them realize the enormity of what happened" (Jessee 2017, p. 108). She defended the government's decision to display genocide victims' remains or to inter them in mass graves, explaining:

In our tradition, when somebody dies, family and friends gather for the burial ceremony. There is a specific number of days of mourning. Once this period is past, the family returns to everyday business. It's over. But following genocide, you bury a person you are not even sure is your relative. Sometimes you are told that your loved ones were thrown or buried in a particular place and when you search, you don't find them. Sometimes you find body parts scattered all over, and you collect the head here, the legs there ... So what we do is we collect all remains and bring them to the memorial. In essence, we are not in opposition to tradition. We are just being practical, adapting to the special situation of genocide.

However, Solange admitted that the government's treatment of the anonymous dead at the memorials had alienated the wider community where she worked, particularly following the 2008 entry into force of a law that required all genocide victims' remains to be reburied at a local memorial (Government of Rwanda 2008). For this reason, Solange alternated between respecting the government's decision to prioritize displaying human remains as physical evidence of the genocide, and empathizing with those survivors for whom the memorials had become a source of anguish, for forcing them to interact with their dead in a manner that defied individual preferences for the respectful treatment of the dead. Solange claimed she had, on occasion, seen survivors take small bones and pieces of clothing from the memorial, presumably with the intention of reburying them on their ancestral lands as a means of facilitating closure or appeasing the angry spirits of their dead. 
And while she acknowledged that people were not supposed to speak about such things, she also admitted that many members of her community, regardless of ethnicity, were angered by the thought of Tutsi victims of the genocide being buried alongside Hutu victims of RPA atrocities - particularly alleged génocidaires who had been murdered by RPA troops - at the memorials (see also Des Forges 1999, pp. 701-35).

Similar concerns emerged from the countless unrecorded casual conversations and related ethnographic encounters that I have had with Rwandans from different ethnic backgrounds since 2007. A central theme within these conversations related to the possible negative impact that the displays of anonymous human remains could have on the lives of the people who came into contact with them. While over the years most of these displays have been protected behind clear plastic or glass, prior to 2012 it was still common for bones to be stacked on open shelves at the genocide memorials, so that visitors could pick them up and examine them as evidence. When speaking with Rwandans about Kwibuka, several people admitted that they feared the memorials because they were worried about the consequences of coming into contact with the remains of people whose blood had been shed in violence. I was frequently told that the spirits of people who had died violent deaths were particularly dangerous, because these angry spirits would lash out at anyone with whom they came in contact - including their own surviving family members - if they felt their remains were being treated disrespectfully. This belief seemed particularly prevalent among the convicted génocidaires I interviewed, who frequently referenced the belief that the blood of their victims was capable of "chasing them". Three convicted génocidaires whom I interviewed in the prisons where they were serving sentences for genocide-related crimes spoke at length about nightmares, unpredictable mood swings and other psychological symptoms, which they attributed to having come into direct contact with the blood of their victims (Jessee 2017, p. 168).

I similarly encountered many Rwandans who avoided going to their local memorials because they perceived these sites to be spiritually dangerous. Such concerns were widespread across Rwanda, but seemed particularly common among the people I encountered around Bisesero - where Tutsi civilians launched a famous resistance against the Hutu Power extremists during the genocide (Gasana 2019). There, I met several people who claimed to have seen or experienced the negative effects of living alongside the angry spirits of people who had died in the resistance. Boniface, a Hutu man who had grown up in Bisesero, recalled that many people were afraid to go to Bisesero because "maybe the ghosts of dead people [referring to the victims of the genocide and related mass atrocities] would attack us". However, he also acknowledged that people sometimes feared these places because "after the genocide, we though there were some killers [referring to Hutu Power extremists] who were still killing people inside the forest, and also survivors [referring to RPA combatants and genocide survivors] who wanted revenge against us [referring to the local Hutu]". When speaking with other 
community members, however, concerns regarding angry spirits seemed more prominent than the risk of violence from Hutu Power extremists or vengeful survivors, perhaps because these risks had dissipated over the years. Conversely, the threat from angry spirits seemed ongoing, inflicting a range of mental and physical illnesses on community members who farmed in places where victims' bodies had been left, as well as allegedly causing infertility among the cattle and goats that the locals attempted to rear. Some people had continued farming in the area out of necessity. However, it seemed that they had negotiated a fragile peace with the angry spirits, whom they were quick to blame for any undue suffering.

These casual conversations touched upon an additional source of tension associated with the memorials, namely the prospect that due to the absence of definitive identification of the anonymous dead interred at the memorials, it was likely that Tutsi victims of the genocide had been interred alongside the Tutsi, Hutu and Twa victims of the mass atrocities perpetrated in the region in the 1990s, as evidence of the "1994 genocide against the Tutsi" (see also Guichaoua 2020, pp. 130-6; Straus 2019). Related concerns were shared with me by Rwandans from a range of ethnic and political backgrounds in unrecorded conversations. Several survivors expressed overt horror at the idea that their missing and murdered loved ones might be interred alongside the same people who murdered them, and cited concerns that this might prevent the genocide's "real victims" from finding peace in the afterlife. Interestingly, I found that several bystanders and convicted génocidaires of Hutu heritage or mixed ethnicity shared similar beliefs, but with anguish and resentment emerging from their perception that their loved ones, who had died in the broader political violence that occurred in the region in the 1990s, would never receive the same recognition afforded to Tutsi genocide victims. Indeed, the arrest and conviction of Victoire Ingabire - a woman of mixed Rwandan heritage and a prominent member of Rwanda's political opposition - for minimizing the genocide, among other allegations, was probably prompted by her 2010 speech at the Kigali Genocide Memorial, during which she noted,

if we look at this memorial, it only stops at people who died during the Tutsi genocide. It does not look at the other side - at the Hutus who died during the genocide. Hutus who lost their people are also sad and they think about their lost ones and wonder, 'When will our dead ones be remembered?'.

(Ingabire 2010; see also Al Jazeera 2018; BBC 2012)

\section{Conclusion: the challenges of commemoration in authoritarian contexts}

Unsurprisingly, given the myriad tensions that surround genocide commemoration in Rwanda, the nation's state-funded memorials and commemorative activities remain in a state of flux. Some changes are in direct response to feedback - both positive and negative - that the CNLG and the 
Rwandan government more generally has received from survivors. For example, in response to concerns that working at the memorials was too challenging for people who had survived, or whose loved ones had been murdered, the Rwandan government introduced a training programme that provides memorial staff with coping strategies for handling the negative psychological consequences of long-term work at these sites (Jessee 2017, pp. 87-8). The government has also increasingly funded improvements and/or renovations of the nation's smaller and more remote memorials, to ensure that evidence of the genocide is preserved. This has typically included placing small displays of anonymous human remains behind clear plastic or glass, and interring all other remains in coffins placed in cement-covered mass graves or crypts, so that people no longer come into direct contact with human remains. Where such improvements are impossible, smaller memorials are incorporated into larger, more sustainable sites. These measures are informed by the Rwandan government's efforts since 2017 to promote agaciro (dignity): a concept that also expresses state ambitions for Rwanda's future beyond commemoration (Bolin 2019). Simultaneously, policy analyst Gretchen Baldwin (2019, p. 10) argues that, since 2014, the Rwandan government has facilitated a shift "from larger, state-performed commemoration events to more intimate community-based events". This allows people to engage with national commemoration in accordance with their personal preferences, facilitating a more multilayered and dynamic Kwibuka period. These changes support Ibreck's (2012, p. 99) argument:

[T] he government cannot impose its authority through commemoration, which necessarily is an opportunity for other voices to be heard. Official efforts to cultivate a selective memory are successful only in part ... public memory serves as the focus for popular demands for justice and rights and therefore acts as a channel for posing challenges to the regime.

However, concerns persist that, amid these important changes in commemorative practices, the Rwandan government continues to prioritize its political interests at the expense of genuine national unity and reconciliation. The state's ongoing efforts to lobby the international community to adopt its official label for the "1994 genocide against the Tutsi" continue to encounter resistance, even as it meets with significant success. As part of these efforts, in 2012, the Rwandan government nominated the genocide memorials at Nyamata, Murambi Bisesero and Kigali to the UNESCO World Heritage List, though UNESCO continues to deliberate their addition (Bolin 2020, p. 200; UNESCO 2012). Extensive international lobbying by the Rwandan government and various Rwandan survivors' organizations subsequently prompted the United Nations General Assembly, in 2018, to rename 7 April "the International Day of Reflection on the 1994 genocide against the Tutsi in Rwanda", even as it encourages participants to acknowledge the Hutu and Twa who died in opposition to the genocide (United Nations 2018). Various 
nations are now debating whether to adopt this language in state discourse: for example, in 2019 the Belgian government set an important precedent by criminalizing denial of the 1994 genocide against the Tutsi (Bizimungu 2019). However, concerns persist internationally that uncritically adopting this label contributes to obscuring non-Tutsi victims of the genocide, and silencing people's experiences of the broader human rights violations that surrounded the genocide in the 1990s. For example, Baldwin concluded that the Rwandan government's current approach to commemoration reinforces "a survivor nationalism diametrically opposed to the homogeneity of the rest of the year", by which she means official efforts to facilitate a shared national identity among Rwandans through eschewing divisive ethnic labels (2019, p. 3).

The case of Rwanda thus raises provocative questions about the potential for genuine social repair - a key intended outcome of transitional justice - to be realized through official commemorative activities and sites, especially when commemorations are informed by regimes that see no benefit to acknowledging the complexity of people's experiences surrounding genocide, as well as broader atrocities that might have occurred in addition to genocide. In other contexts, such as post-civil war Uganda, transitional justice scholars have argued that creating culturally appropriate public spaces in which people can talk about their complex first-hand experiences of violence allows storytelling to restore social equilibrium (see, for example, Baines and Stewart 2011). More generally, anthropologists Veena Das and Arthur Kleinman (2001, p. 6) have maintained that "[f]inding one's voice in the making of one's history, the remaking of a world ... is also a matter of being able to re-contextualize the narratives of devastation and generate new contexts through which everyday life may become possible". However, in considering the possibility that creating space for people to speak earnestly about their complex experiences of genocide and related mass atrocities, it is important to heed anthropologist Kirstin Doughty's (2015, p. 432) warning that, while it might be tempting to imagine that there are some post-conflict contexts "where a kinder, gentler reconciliation can occur, absent power relations of age, gender, class, or other forms of silencing", in many contexts "the work of building and rebuilding social networks among "intimate enemies" ... is contentious, suffused with hostility and instrumentality". Thus, it is unlikely that official commemorations and other collective forms of remembering mass atrocities, whatever form they may take in future, will ever prove satisfying to everyone - a point that transitional justice scholars and practitioners would do well to remember in evaluating the "success" of efforts to promote social repair in post-genocide contexts.

\section{Note}

1 All interviewees' names have been replaced with pseudonyms in accordance with their individual preferences and the terms of the informed consent process underlying the author's fieldwork in Rwanda. 


\section{References}

Al Jazeera. "Rwanda opposition leader among 2,100 released from prison". Al Jazeera, 14 September 2018, www.aljazeera.com/news/2018/9/15/rwandan-opposi tion-leader-among-2100-released-from-prison. Accessed 17 February 2021.

Bagilishya, Déogratias. "Mourning and recovery from trauma: In Rwanda, tears flow within". Transcultural Psychiatry, vol. 37, no. 3,2000, pp. 337-353.

Baines, Erin, and Beth Stewart. "I cannot accept what I have not done': Storytelling, gender, and transitional justice". Journal of Human Rights Practice, vol. 3, no. 3, 2011, pp. 245-263.

Baldwin, Gretchen. "Constructing identity through commemoration: Kwibuka and the rise of survivor nationalism in post-conflict Rwanda". Journal of Modern African Studies, vol. 57, no. 3, 2019, pp. 1-21.

BBC. "Rwandan opposition leader Victoire Ingabire jailed". BBC, 30 October 2012, www.bbc.co.uk/news/world-africa-20138698. Accessed 17 February 2021.

Benda, Richard. "Promising generations: From intergenerational guilt to Ndi Umunyarwanda". Rwanda since 1994: Stories of change, edited by Hannah Grayson and Nicki Hitchcott. Liverpool, Liverpool University Press, 2019, pp. 189-210.

Bizimungu, Julius. "How significant is Belgium's move to criminalise genocide denial?" The New Times, 10 April 2019, www.newtimes.co.rw/news/how-significa nt-belgiums-move-criminalise-genocide-denial. Accessed 25 January 2021.

Blackie, Laura, and Nicki Hitchcott. "II am Rwandan': Unity and reconciliation in post-genocide Rwanda". Genocide Studies and Prevention, vol. 12, no. 1, 2018, pp. 24-37.

Bolin, Annalisa. "Dignity in death and life: Negotiating agaciro for the nation in preservation practice at Nyamata Genocide Memorial, Rwanda". Anthropological Quarterly, vol. 92, no. 2, 2019, pp. 345-374.

Bolin, Annalisa. "Imaging genocide heritage: Material modes of development and preservation in Rwanda". Journal of Material Culture, vol. 25, no. 2, 2020, pp. 196219.

Buckley-Zistel, Susanne. "Remembering to rorget: Chosen amnesia as a strategy for local coexistence in post-genocide Rwanda". Africa, vol. 76, no. 2, 2006, pp. 131150.

Burnet, Jennie. Genocide lives in us: Memory and Silence in Rwanda. Madison, University of Wisconsin Press, 2012.

Burnet, Jennie. "Uwilingiyimana, Agathe". Oxford Research Encyclopedia of African History. London, Oxford University Press, 2019.

Burnet, Jennie. "Whose genocide? Whose truth? Representation of victim and perpetrator in Rwanda". Genocide: Truth, memory, and representation, edited by Alexander Hinton and Kevin O’Neill. Durham, NC, Duke University Press, 2009, pp. 80-110.

Das, Veena, and Arthur Kleinman. "Introduction". Remaking a world: Violence, social suffering, and recovery, edited by Veena Das and Arthur Kleinman. Berkeley, University of California Press, 2001, pp. 1-30.

Degni-Ségui, René. "Report on the situation of human rights in Rwanda, submitted by Mr. René Degni-Ségui, Special Rapporteur of the Commission on Human Rights, under paragraph 20 of Resolution S-3/1 of 25 May 1994”. United Nations Commission on Human Rights, 29 January 1996, http://hrlibrary.umn.edu/comm ission/country52/68-rwa.htm. Accessed 25 January 2021. 
Des Forges, Alison. Leave none to tell the story: Genocide in Rwanda. New York, Human Rights Watch, 1999.

Doughty, Kristin. "Law and the architecture of social repair: Gacaca days in postgenocide Rwanda". Journal of the Royal Anthropological Institute, vol. 21, no. 2, 2015, pp. 419-437.

Doughty, Kristin. Remediation in Rwanda: Grassroots legal forums. Philadelphia, University of Pennsylvania Press, 2016.

Drozdzewski, Danielle, Sarah De Nardi, and Emma Waterton. Memory, place and identity: Commemoration and remembrance of war and conflict. London, Routledge, 2016.

Eltringham, Nigel, and Saskia Van Hoyweghen. "Power and identity in post-genocide Rwanda". Politics of Identity and Economics of Conflict in the Great Lakes Region, edited by Ruddy Doom and Jan Gorus. Brussels, VUB University Press, 2000, pp. 215-242.

Friedrich, Mona, and Tony Johnston. "Beauty versus tragedy: Thanatourism and the memorialisation of the 1994 Rwandan genocide". Journal of Tourism and Cultural Change, vol. 11, no. 4, 2013, pp. 302-320.

Gahima, Gerald. Transitional justice in Rwanda: Accountability for atrocity. London, Routledge, 2013.

Gasana, Oscar. Les collines se souviennent: Les rescapés de Bisesero racontent leur résistance, deux décennies après le génocide des Tutsi du Rwanda. Kigali, Izuba, 2019.

Government of Rwanda. Law No. 56/2008 of 10/09/2008 Governing Memorial Sites and Cemeteries of Victims of the Genocide Against the Tutsi in Rwanda. Kigali, Government of Rwanda, 2008.

Guichaoua, André. "Counting the Rwandan victims of war and genocide: Concluding reflections". Journal of Genocide Research, vol. 22, no. 1, 2020, pp. 125-144.

Guichaoua, André. From war to genocide: Criminal politics in Rwanda, 1990-1994. Madison, University of Wisconsin Press, 2015.

Guyer, Sara. "Rwanda's bones". Boundary 2, vol. 36, no. 2, 2009, pp. 155-175.

Hintjens, Helen. "Post-genocide identity politics in Rwanda". Ethnicities, vol. 8, no. 1, 2008, pp. 5-41.

Ibreck, Rachel. "International constructions of national memories: The aims and effects of foreign donors' support for genocide remembrance in Rwanda". Journal of Intervention and Statebuilding, vol. 7, no. 2, 2013, pp. 149-169.

Ibreck, Rachel. "The politics of mourning: Survivor contributions to memorials in post-genocide Rwanda”. Memory Studies, vol. 3, no. 4, 2010, pp. 330-343.

Ibreck, Rachel. "A time of mourning: The politics of commemorating the Tutsi genocide in Rwanda". Public memory, public media and the politics of justice, edited by Philip Lee and Pradip Thomas. London, Palgrave Macmillan, 2012, pp. 99-120.

Ingabire, Victoire. Unity and reconciliation speech at Gisozi Genocide Memorial Centre. 2010. www.victoire-ingabire.com/Eng/victoires-quotes/. Accessed 17 February 2021.

Ingelaere, Bert. Inside Rwanda's gacaca courts: Seeking justice after genocide. Madison, University of Wisconsin Press, 2016.

International Criminal Court. "Rome Statute of the International Criminal Court". 1998, www.icc-cpi.int/resource-library/documents/rs-eng.pdf. Accessed 25 January 2021.

Jessee, Erin. Negotiating genocide in Rwanda: The politics of history. Cham, Palgrave Macmillan, 2017. 
Jessee, Erin. "Promoting reconciliation through exhuming and identifying victims in the 1994 Rwandan genocide". Discussion Paper Series no. 4, Waterloo, ON, Centre for International Governance Innovation, 2012, pp. 2-22.

Jessee, Erin. "Rwandan women no more: Female genocidaires in the aftermath of the 1994 Rwandan genocide”. Conflict and Society, vol. 1, 2015, pp. 60-80.

Kagame, Paul. "Speech on the occasion of 26th commemoration of genocide against Tutsi". The New Times, 7 April 2020, www.newtimes.co.rw/news/speech-president-ka game-launch-26th-commemoration-genocide-against-tutsi. Accessed 25 January 2021.

Kimonyo, Jean-Paul. Rwanda's popular genocide: A perfect storm. Boulder, CO, Lynne Rienner Publishers, 2016.

King, Elisabeth. "Memory controversies in post-genocide Rwanda: Implications for peacebuilding". Genocide Studies and Prevention, vol. 5, no. 3, 2010, pp. 293-309.

Kubai, Anne. "Post-genocide Rwanda: The changing religious landscape". Exchange. vol. 36, 2007, pp. 198-214.

Laws, Meghan, Richard Ntakirutimana, and Bennett Collins. "One Rwanda for all Rwandans': (Un)covering the Twa in post-genocide Rwanda”. Rwanda since 1994: Stories of change, edited by Hannah Grayson and Nicki Hitchcott. Liverpool, Liverpool University Press, 2019, pp. 125-145.

Lewis, Jerome, and Judy Knight. "The Twa of Rwanda: An assessment of the situation of the Twa and promotion of Twa rights in post-war Rwanda". Chadlington, World Rainforest Movement and International Work Group for Indigenous Affairs, 1995.

Longman, Timothy. Christianity and genocide in Rwanda. Cambridge, Cambridge University Press, 2010.

Longman, Timothy, and Théoneste Rutagengwa. "Memory and violence in postgenocide Rwanda". States of violence: Politics, youth, and memory in contemporary Africa, edited by Edna Bay and Donald Donham. Charlottesville, University of Virginia Press, 2006, pp. 236-260.

Major, Laura. "Unearthing, untangling, and re-articulating genocide corpses in Rwanda”. Critical African Studies, vol. 7, no. 2, 2015, pp. 164-181.

Meierhenrich, Jens. "How many victims were there in the Rwandan genocide? A statistical debate". Journal of Genocide Research, vol. 22, no. 1, 2020, pp. 72-82.

Meierhenrich, Jens. "The transformation of lieux de mémoire in Rwanda". Remaking Rwanda: State building and human rights after mass violence, edited by Scott Straus and Lars Waldorf. Madison, University of Wisconsin Press, 2011, pp. 283-296.

Mwambari, David. "Music and the politics of the past: Kizito Mihigo and music in the commemoration of the genocide against the Tutsi in Rwanda". Memory Studies, vol. 13, no. 6, 2019, pp. 1-16.

National Commission for the Fight Against Genocide. Genocide. 2013, www.cnlg.gov. rw/-Genocide-.html. Accessed 25 January 2021.

National Commission for the Fight Against Genocide. National Genocide Memorial Sites. 2020, https://cnlg.gov.rw/index.php?id=81. Accessed 25 January 2021.

Ngoga, Martin. "Resolution on genocide against the Tutsi offers clarity over the massacre". The East African, 8 June 2020, www.theeastafrican.co.ke/oped/comm ent/Resolution-on-genocide-clarity-over-the-massacre/434750-5571924-159ykv1/ind ex.html. Accessed 25 January 2021.

Nowrojee, Binaifer. Shattered lives: Sexual violence during the Rwandan genocide and its aftermath. New York, Human Rights Watch, 1996.

Rose, Julia. Interpreting difficult history at museums and historic sites. Lanham, MD, Rowman \& Littlefield, 2016. 


\section{Erin Jessee}

Rugira, Lonzen. "Genocide against the Tutsi has passed moral, legal, and political tests". The New Times, 16 April 2020, www.newtimes.co.rw/opinions/genocide-aga inst-tutsi-has-passed-moral-legal-and-political-tests. Accessed 25 January 2021.

Schofield, Hugh. "Rwanda genocide: Kagame 'cleared of Habyarimana crash"”. BBC, 10 January 2012, www.bbc.co.uk/news/world- africa-16472013. Accessed 25 January 2021.

Segal, Aaron. "Massacre in Rwanda". Fabian Research Series, vol. 240, no. 23, 1964, https://repositories.lib.utexas.edu/bitstream/handle/2152/19491/oclc2218385.pdf;seq uence $=2$. Accessed 25 January 2021.

Sodaro, Amy. Exhibiting atrocity: Memorial museums and the politics of past violence. New Brunswick, NJ, Rutgers University Press, 2018.

Straus, Scott. "The limits of a genocide lens: Violence against Rwandans in the 1990s". Journal of Genocide Research, vol. 21, no. 4, 2019, pp. 504-524.

Trédivic, Marc, and Nathalie Poux. "Rapport d'expertise: Destruction en vol du Falcon 50". Cour d'appel de Paris, 2012, http://ddata.over-blog.com/xxxyyy/2/ 93/ 44/38/rapport-ballist-attentat-contre-habyarimana-6-4-19- copie-1.pdf. Accessed 25 January 2021.

UNESCO World Heritage Centre. Sites mémoriaux du génocide: Nyamata, Murambi, Bisesero et Gisozi. 2012, whc.unesco.org/en/tentativelists/5753/. Accessed 25 January 2021.

United Nations. Convention on the Prevention and Punishment of the Crime of Genocide. 1948, https://treaties.un.org/doc/publication/unts/volume\%2078/volume-78-i-1021-engl ish.pdf. Accessed 25 January 2021.

United Nations. General Assembly Designates 7 April International Day of Reflection on 1994 Genocide against Tutsi in Rwanda, Amending Title of Annual Observance. 2018, www.un.org/press/en/2018/ga12000.doc.htm. Accessed 25 January 2021.

Van Hoyweghen, Saskia. "The disintegration of the Catholic Church of Rwanda: A study of the fragmentation of political and religious authority". African Affairs, vol. 95 , no. 380,1996 , pp. 379-401.

Vidal, Claudine. "La commemoration du genocide au Rwanda: Violence symbolique, memorisation force et histoire officielle". Cahiers d"études africaines, vol. 44, no. 175, 2004, pp. 575-592.

Viebach, Julia. "Mediating 'absence-presence' at Rwanda's genocide memorials: Of care-taking, memory and proximity to the dead". Critical African Studies, vol. 12, no. 2, 2020, pp. 237-269.

Viebach, Julia. "Of other times: Temporality, memory and trauma in post-genocide Rwanda”. International Review of Victimology, vol. 25, no. 3, 2019, pp. $277-301$.

Winter, Paul. Memorial museums: The global rush to commemorate atrocities. New York, Berg, 2007. 